\title{
IDŐJÁRÁS
}

Quarterly Journal of the Hungarian Meteorological Service

Vol. 125, No. 3, July-September, 2021, pp. 449-462

\section{Influence of climate change on river discharges over the Sava River watershed in Bosnia and Herzegovina}

\author{
Slobodan Gnjato", Tatjana Popov, Dragutin Adžić, Marko Ivanišević, \\ Goran Trbić, and Davorin Bajić
}

\author{
University of Banja Luka \\ Faculty of Natural Sciences and Mathematics \\ Department of Geography \\ Mladena Stojanovića 2, Banja Luka, \\ Republic of Srpska, Bosnia and Herzegovina \\ *Corresponding Author e-mail: slobodan.gnjato@pmf.unibl.org
}

(Manuscript received in final form September 1, 2020)

\begin{abstract}
The paper examines changes in air temperature, precipitation, and river discharges on seasonal and annual scale over the Sava River watershed in Bosnia \& Herzegovina during the period 1961-2016. Based upon data gathered from 11 meteorological stations and 3 hydrological stations, hydroclimatic variables trends were established by utilizing the nonparametric Mann-Kendall test and the nonparametric Sen's slope estimator. The results show significant positive seasonal and annual trends (expect for autumn, during which upward trends were insignificant) in air temperature, whereas both positive and negative insignificant seasonal and annual precipitation trends are shown where determined for the entire watershed. Most prominent upward trends in air temperature were found in summer and afterwards in winter and spring, indicating a pronounced warming tendency over the Sava River watershed. Trends in river discharge displayed a negative tendency in all seasons. Nevertheless, a majority of estimated trends of river discharges were weak and statistically insignificant. Throughout the year, river discharges showed significant positive correlation with precipitation, whilst connection with air temperature was mostly significant and negative. The study results suggest that climate is an important factor affecting river regimes, as well as that changes in river discharges are reflecting recent abrupt changes in climatic variables.
\end{abstract}

Key-words: climate change, temperature, precipitation, river discharges, correlation, Sava River watershed 


\section{Introduction}

On a global scale, river discharge patterns have been modified by climate system warming and numerous human actions (Schneider et al., 2013; Su et al., 2018). In many cases, climate change can amplify effects of human activities. Climate is one of a key drivers of freshwater ecosystem processes, as river discharge and river thermal regimes are closely tied to climatic variations. Alteration of principal climate connected drivers, such as increased temperature and modified precipitation patterns, have substantial influence on river discharge regimes and are predicted to affect hydrological cycle (Kong and Pang, 2013; van Vliet et al., 2013). Hydroclimatic intensification in the context of recent global warming can result in shift in distribution and magnitude of wet/dry periods (Madakumbura et al., 2019). The global rise in air temperature is expected to increase the portion of precipitation to fall as a rainfall along with the number of extreme rainfall events, reduce snowfall, and cause earlier spring melting of snow cover which will have severe impact, especially in alpine river basins which are strongly regulated by the accumulation of snow (Kormann et al., 2015; Rottler et al., 2020). Comprehension of hydrological dynamics of river discharge patterns, as response to recent climate variation is essential for beneficial water management as water resources in many regions have been affected in regard to volume and quality condition (Biao, 2017; Jiménez Cisneros et al., 2014). Consequently, in order to analyze climate change impact on water resources and to build proper water management approaches, it is mandatory to determine trends and connections between river discharges and rainfall/temperature (Gebremicael et al., 2017; Lorenzo-Lacruz et al., 2012). Worldwide, extensive research on river discharges has been conducted at different spatio-temporal scales. Recent trends in river discharges had been determined in North America (Déry et al., 2016; Tamaddun et al., 2016), South America (Pasquini and Depetris, 2007), Africa (Saraiva Okello et al., 2015; Sidibe et al., 2018), Asia (Souvignet, et al., 2014; Tananaev et al., 2016), and Australia (Zhang et al., 2016). Comparable researches were also undertaken in Europe. In recent pan-European studies Masseroni et al. (2020) and Stahl et al. (2010) both found downward river flow trends in the southern and eastern parts of Europe, whereas positive trends were determined in northern areas of the continent. Such patterns of river discharge changes have also been confirmed by studies on a lower scale - in Spain (Yeste et al., 2018), Italy (Billi and Fazzini, 2017), the United Kingdom (Hannaford and Buys, 2012), the Nordic Region (Wilson, et al., 2010), etc. Streamflow trends research over southeastern part of Europe, conducted at different spatial scales, also suggest downward tendencies of streamflow in this region. River discharge trends at 94 stations in Serbia displayed downward tendencies of annual, winter, spring, and summer discharges, whereas upward trends occurred in autumn (Kovačević-Majkić and Urošev, 2014). Observed trends were mainly insignificant (73\% on annual and $76-86 \%$ on seasonal scale). Oppositely, in a study of river discharges at 24 
stations in the central region of Serbia Dimkić (2018) reported more often occurrence of significant positive/negative annual trends claiming that they appear as a consequence of anthropogenic water consumption. Research on natural streamflow in North Macedonia indicates negative annual and seasonal trends over the whole territory, while no significant upward trend has been noted (Radevski et al., 2018). Significant decline in mean annual discharges was found at $31 \%$ of stations, whereas most prominent decrease on seasonal level was found in summer at $39 \%$ of stations. A streamflow trend analysis from 44 near-natural river basins in Romania showed increase at $16 \%$ and decrease at $20 \%$ of total number of stations in mean annual river flows (Birsan et al., 2014). Significant downward trends were found in summer, whereas significant increasing tendency was observed in winter and autumn. Trends in annual streamflow at 54 stations in Croatia for the most part were negative and statistically insignificant (Čanjevac and Orešić, 2015). As in previous cases, the most prominent downward trends were observed in summer, while upward trends were present in winter and autumn. The Morača River in Montenegro, which is the largest tributary of Skadar Lake, shows a significant downward trend in the mean annual flow for the period 1951-2010. However, in the period 1991-2010 there is an increasing trend of the mean annual flow, which is a consequence of the growth of the annual precipitation in the Morača River basin (Burić et al., 2016). Mostly insignificant negative streamflow trends were observed throughout the Sava River basin (mainly in the lower and middle sections of the basin) at $50 \%$ of stations located over Slovenia, Croatia, Bosnia and Herzegovina (B\&H), Montenegro, and Serbia (Lutz et al., 2016). Relatively similar streamflow trend patterns were found for some Sava River sub-basins in Croatia (Orešić et al., 2018), B\&H (Hadžić and Drešković, 2014), and Serbia (Burić et al., 2012).

Warming of the climate system in lately years and decades has been confirmed on global (Fei et al., 2014; IPCC, 2014), continental [such as Europe (van der Schrier et al., 2013)], and regional [such as Sava River Basin (Bajat et al., 2015; Burić et al., 2014; Mamara et al., 2016)] levels. In B\&H, increase in mean and extreme air temperatures was determined over the entire territory, especially in the northern areas which represent the lower parts of the Sava River watershed (SRW) (Popov et al., 2018a; Trbić et al., 2017). As opposed to air temperature, relatively distinguished precipitation patterns with insignificant trends have been reported on global scale (Adler et al., 2017; Gu \& Adler, 2015). Precipitation patterns in B\&H and in the Sava River basin are principally manifested in insignificant increase/decrease in mean and extreme values (Luković et al., 2014; Popov et al., 2018b; Gajić-C Cipka et al., 2015). Area of the SRW in B\&H is an important area to investigate changes in river discharges since this area is projected to experience severe climate change impact in the later half of 21 st century (Radusin et al., 2016). The objectives of this paper were to identify annual and seasonal trends in hydrological and climatic data series, whereas the main goal was to evaluate climate change connection/influence on river discharges in Sava River sub-basins in B\&H. 
In order to minimize the anthropogenic influence and to determine the influence of climate change on river discharges, unregulated rivers with continual long-term measurements were chosen for the investigation.

\section{Study area}

Approximately $40 \%\left(38,719 \mathrm{~km}^{2}\right)$ of SRW is located on the territory of B\&H, while the rest of the watershed is shared by Slovenia, Croatia, Serbia, Montenegro and Albania. The total river length is about $944 \mathrm{~km}$, whereas the length of the flow through Bosnia and Herzegovina is $302 \mathrm{~km}$. The SRW in B\&H covers central (Dinaric) and northern (Peripannonian) regions which make a total of $75 \%$ of the entire country (Fig. 1). The climate of the basin changes from mountain climate in the upper part to continental and moderate continental climate in the mid and lower floodplain sections of the watershed. From the southern mountainous part of the watershed towards the lowland area in the north, precipitation decreases, whereas air temperature increase (Popov et al., 2018c; Trbić et al., 2017). Major Sava affluents in B\&H are the Una River (210 km), Vrbas River (250 km), Bosna River $(275 \mathrm{~km})$, and Drina River $(345 \mathrm{~km})$. The Sana River $(146 \mathrm{~km})$ is the greatest affluent of the Una River, while the Vrbanja River $(95 \mathrm{~km})$ is the major affluent of the Vrbas River. All major affluents of the Sava River are defined by the pluvial-nival river regimes (Ilešič, 1948), i.e., maximum values of discharge occur in the spring, while minimum values of river discharges take place in the summer season.

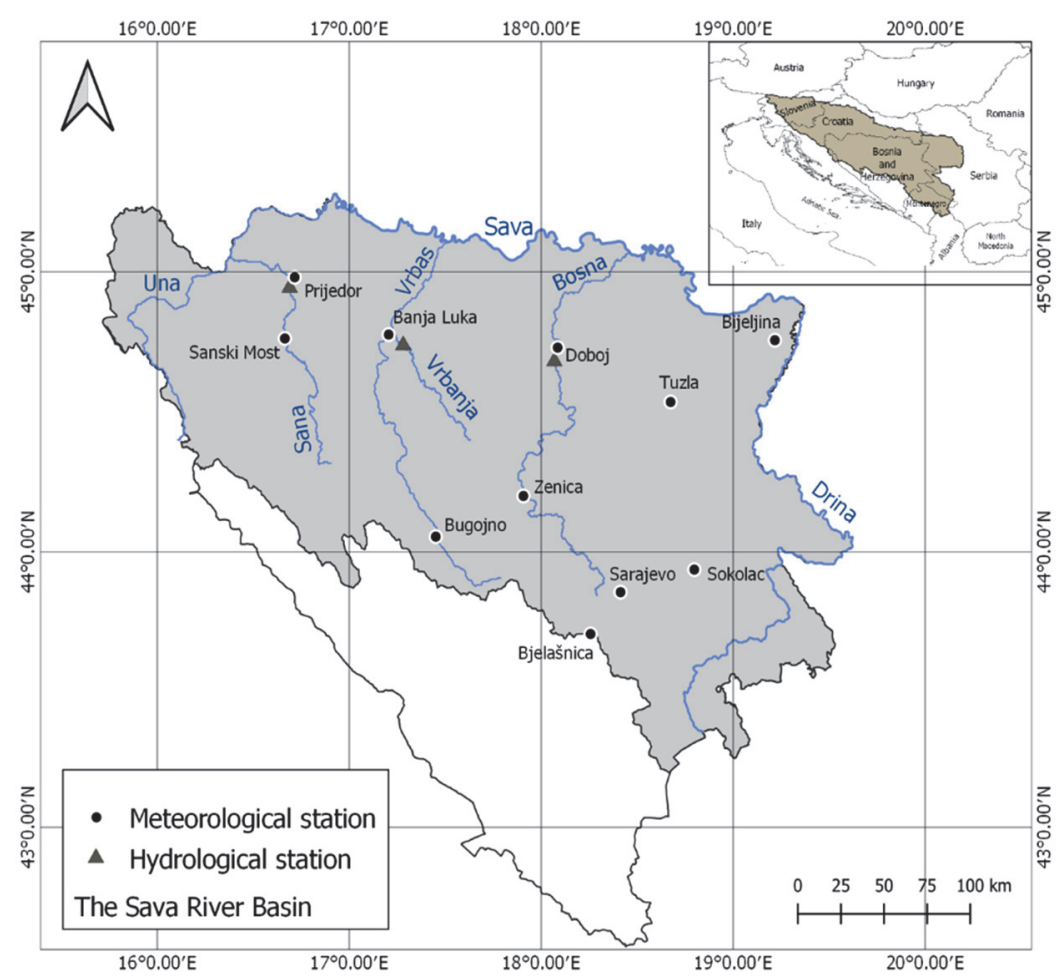

Fig. 1. Geographical location of the Sava River basin in Bosnia and Herzegovina with the meteorological and hydrological stations 


\section{Data and methods}

Annual and seasonal discharges trends over the SRW during the period 19612016 were determined by using the data on mean monthly discharges from three hydrological stations (Prijedor, Vrbanja, and Doboj) located in the northern section of the watershed. The selected hydrological stations were chosen due to the fact they are the only three stations on unregulated streamflow in the whole country with continuous long-term measurements. The absence of a larger number of hydrological stations with long-term and undisturbed measurements was caused by the war events during the 1990s. As a result, the operation of a considerable number of stations was stopped for 10 or more years, while some stations stopped operating for good and some changed location.

Analysis of climatic variables in the period 1961-2016 was done based on data on mean monthly air temperatures and precipitation gathered from 11 weather stations positioned in various sections of the study area. Data on climatic and hydrological variables were delivered by the Republic Hydrometeorological Service (Republic of Srpska) and by the Federal Hydrometeorological Institute.

In order to identify statistically significant monotonic downward or upward trends, hydroclimatic data values were exposed to the nonparametric MannKendall trend test and the nonparametric Sen's estimator of slope. The MannKendall trend test is commonly applied to establish trends in hydroclimatic temporal sequences (Wang et al., 2015), while it is especially suitable for identifying discharge trends, since the hydrological time series data are not affected by distribution and missing values (Gebremicael et al., 2017). The Sen's nonparametric estimator is applied to assess trend magnitude. The statistical significance of the estimated trend values was specified at the $99 \%(\mathrm{p} \leq 0.01)$ and $95 \%(0.01<\mathrm{p} \leq 0.05)$ levels. Connection among climatic variables and river discharges was determined by applying the Pearson correlation coefficient. Correlation analysis was performed for pairs of the nearest hydrological and meteorological stations. Correlation between river discharges and precipitation/air temperature can help us to reveal how climate affects river discharges as well as the connection between them. For instance, positive correlation among precipitation and river discharges suggests that changes in river discharges occur in consistency with changes in precipitation, while positive correlation among river discharges and air temperature could indicate the prevailing influence of snowmelt water in relation to evapotranspiration (negative correlation would indicate oppositely) (Cuo et al., 2014).

All calculations were completed using the XLSTAT statistical software (version 2014.5.03). 


\section{Results and disscusion}

\subsection{Changes in climatic variables}

Seasonal and annual averages of air temperatures and precipitation measured at 11 meteorologicaal stations over the SRW in B\&H during the period 1961-2016 are displayed in Table 1. Mean annual temperature in the SRW increases from $1.5^{\circ} \mathrm{C}$ in the southern mountain zone to $11.0-11.5^{\circ} \mathrm{C}$ in the northern lowland region. Summer is the warmest season with mean air temperatures in the range from $9.4-16.0{ }^{\circ} \mathrm{C}$ in the upper to $20.6-21.3{ }^{\circ} \mathrm{C}$ in the lower part of the basin. Winter is the coldest season with mean temperatures ranging from $-5.9-0.0^{\circ} \mathrm{C}$ in the south to $1.3-1.4{ }^{\circ} \mathrm{C}$ in the north. Annual precipitation ranges from $1201 \mathrm{~mm}$ at the highest-located station in the south to $743 \mathrm{~mm}$ in the most northeastern station, and decreases as we move from the western and southern areas of the watershed towards the northeast. Precipitation regime across the vast majority of the watershed is characterized by wet autumn seasons and drier winters.

Table 1. Average values of seasonal and annual climatic variables measured at 11 meteorologicaal stations over the Sava River watershed in Bosnia and Herzegovina in the period 1961-2016

\begin{tabular}{ccccccccccc}
\hline \hline Staion & \multicolumn{2}{c}{ Winter } & \multicolumn{2}{c}{ Spring } & \multicolumn{2}{c}{ Summer } & \multicolumn{2}{c}{ Autumn } & \multicolumn{2}{c}{ Year } \\
& $\left({ }^{\circ} \mathbf{C}\right)$ & $\begin{array}{c}\mathbf{R} \\
(\mathbf{m m})\end{array}$ & $\begin{array}{c}\mathbf{T} \\
\left({ }^{\circ} \mathbf{C}\right)\end{array}$ & $\begin{array}{c}\mathbf{R} \\
(\mathbf{m m})\end{array}$ & $\begin{array}{c}\mathbf{T} \\
\left({ }^{\circ} \mathbf{C}\right)\end{array}$ & $\begin{array}{c}\mathbf{R} \\
(\mathbf{m m})\end{array}$ & $\begin{array}{c}\mathbf{T} \\
\left({ }^{\circ} \mathbf{C}\right)\end{array}$ & $\begin{array}{c}\mathbf{R} \\
(\mathbf{m m})\end{array}$ & $\begin{array}{c}\mathbf{T} \\
\left({ }^{\circ} \mathbf{C}\right)\end{array}$ & $\begin{array}{c}\mathbf{R} \\
(\mathbf{m m})\end{array}$ \\
\hline \hline SM & 1.0 & 226 & 10.7 & 264 & 19.6 & 272 & 10.8 & 281 & 10.6 & 1042 \\
PR & 1.0 & 197 & 11.3 & 231 & 20.6 & 246 & 11.2 & 263 & 11.0 & 934 \\
BL & 1.4 & 227 & 11.4 & 266 & 20.6 & 284 & 11.3 & 266 & 11.2 & 1040 \\
DB & 1.3 & 198 & 11.3 & 232 & 20.3 & 274 & 11.3 & 228 & 11.1 & 929 \\
BN & 1.4 & 159 & 11.8 & 191 & 21.1 & 221 & 11.7 & 175 & 11.5 & 743 \\
TZ & 1.0 & 184 & 10.6 & 228 & 19.4 & 284 & 10.7 & 212 & 10.4 & 906 \\
ZE & 0.9 & 171 & 10.9 & 197 & 19.8 & 219 & 10.9 & 219 & 10.6 & 805 \\
BU & 0.0 & 186 & 9.4 & 208 & 18.2 & 206 & 9.8 & 248 & 9.3 & 846 \\
SO & -2.6 & 181 & 6.8 & 209 & 16.0 & 233 & 7.5 & 239 & 6.9 & 859 \\
SA & 0.6 & 226 & 9.8 & 228 & 18.9 & 234 & 10.5 & 259 & 10.0 & 943 \\
BJ & -5.9 & 273 & -0.4 & 269 & 9.4 & 297 & 2.8 & 366 & 1.5 & 1201 \\
\hline
\end{tabular}

Seasonal and annual linear trends of climatic variables in the period 19612016 are shown in Table 2 and Fig. 2. Significant $(\mathrm{p}<0.01)$ positive trends in mean annual temperatures were established across the whole study area. Estimated warming trend in the SRW was in the scope of $0.2-0.5^{\circ} \mathrm{C} / 10$ years with the lowest and highest warming rate recorded at Bjelašnica (highest-located station) and at 
Prijedor and Banja Luka, respectively. Despite the fact that positive upward trends were observed throughout the year, the most striking warming tendency was determined in summer, during which significant $(p<0.01)$ trends were present over the entire watershed. Summer temperature rise was in the scope of 0.4$0.6{ }^{\circ} \mathrm{C} / 10$ years. Most prominent trends were determined for the northern part of the SRW (Prijedor, Banja Luka, and Bijeljina). Almost the entire area has also faced significant positive temperature trends in winter $\left(0.4-0.6{ }^{\circ} \mathrm{C} / 10 \mathrm{years}\right)$ and spring $\left(0.2-0.4^{\circ} \mathrm{C} / 10\right.$ years $)$, whereas mainly insignificant positive trends were observed in autumn $\left(0.1-0.3{ }^{\circ} \mathrm{C} / 10\right.$ years $)$. Significant tendency in autumn was only determined in Prijedor and Banja Luka.

Unlike consistent temperature patterns, annual and seasonal precipitation were subjected to mainly insignificant trends of both signs. Insignificant rise in annual precipitation over most of the SRW was detected, whereas insignificant decrease was found in Prijedor, Banja Luka, and Tuzla. Estimated trend values were statistically insignificant at majority of the stations, apart from two mountain stations, Bjelašnica and Sokolac $(84.3 \mathrm{~mm} / 10 y$ years and $38.1 \mathrm{~mm} / 10 y e a r s$, respectively). Most prominent positive seasonal trends were determined over the SRW in autumn (4.2-27.2 mm/10years) and spring (0.5-24.2 mm/10years). Significant upward trends in those seasons were registered in the southern basin area (Bjelašnica and Sokolac). Summer precipitation displayed trends mixed in sign with decline (-14.0$-3.4 \mathrm{~mm} / 10$ years $)$ in the northern areas and increase $(2.5-6.7 \mathrm{~mm} / 10$ years $)$ in the southern part (expect in Sarajevo). Mainly insignificant trends of both sings were found in winter, where precipitation revealed spatially incoherent patterns of change.

Table 2. Decadal linear trends in average seasonal and annual climatic variables measured at 11 meteorologicaal stations over the Sava River watershed in Bosnia and Herzegovina in the period 1961-2016

\begin{tabular}{ccccccccccc}
\hline \hline \multirow{2}{*}{ Station } & \multicolumn{2}{c}{ Winter } & \multicolumn{2}{c}{ Spring } & \multicolumn{2}{c}{ Summer } & \multicolumn{2}{c}{ Autumn } & \multicolumn{2}{c}{ Year } \\
& $\begin{array}{c}\mathbf{T} \\
(\mathbf{C})\end{array}$ & $\begin{array}{c}\mathbf{R} \\
(\mathbf{m m})\end{array}$ & $\begin{array}{c}\mathbf{T} \\
\left({ }^{\circ} \mathbf{C}\right)\end{array}$ & $\begin{array}{c}\mathbf{R} \\
(\mathbf{m m})\end{array}$ & $\begin{array}{c}\mathbf{T} \\
\left({ }^{\circ} \mathbf{C}\right)\end{array}$ & $\begin{array}{c}\mathbf{R} \\
(\mathbf{m m})\end{array}$ & $\begin{array}{c}\mathbf{T} \\
\left({ }^{\circ} \mathbf{C}\right)\end{array}$ & $\begin{array}{c}\mathbf{R} \\
(\mathbf{m m})\end{array}$ & $\begin{array}{c}\mathbf{T} \\
\left({ }^{\circ} \mathbf{C}\right)\end{array}$ & $\begin{array}{c}\mathbf{R} \\
\mathbf{m m})\end{array}$ \\
\hline \hline $\mathrm{SM}$ & $\mathbf{0 . 4}$ & 4.9 & $\mathbf{0 . 3}$ & 2.1 & $\mathbf{0 . 4}$ & -14.0 & 0.1 & 11.1 & $\mathbf{0 . 3}$ & 4.4 \\
$\mathrm{PR}$ & $\mathbf{0 . 4}$ & 0.7 & $\mathbf{0 . 4}$ & 0.7 & $\mathbf{0 . 6}$ & -12.1 & 0.2 & 11.3 & $\mathbf{0 . 5}$ & -2.0 \\
$\mathrm{BL}$ & $\mathbf{0 . 5}$ & 1.4 & $\mathbf{0 . 4}$ & 0.5 & $\mathbf{0 . 6}$ & -14.0 & $\mathbf{0 . 3}$ & 7.0 & $\mathbf{0 . 5}$ & -7.8 \\
$\mathrm{DB}$ & $\mathbf{0 . 4}$ & 0.4 & $\mathbf{0 . 3}$ & 8.4 & $\mathbf{0 . 4}$ & -3.7 & 0.1 & 8.5 & $\mathbf{0 . 3}$ & 19.8 \\
$\mathrm{BN}$ & $\mathbf{0 . 4}$ & -1.1 & $\mathbf{0 . 4}$ & 9.4 & $\mathbf{0 . 6}$ & -4.3 & 0.2 & 5.3 & $\mathbf{0 . 4}$ & 9.9 \\
$\mathrm{TZ}$ & 0.4 & -4.6 & 0.2 & 2.1 & $\mathbf{0 . 4}$ & -3.4 & 0.1 & 9.3 & $\mathbf{0 . 3}$ & -0.6 \\
$\mathrm{ZE}$ & $\mathbf{0 . 6}$ & 1.2 & $\mathbf{0 . 3}$ & 2.3 & $\mathbf{0 . 5}$ & 6.6 & 0.3 & 5.0 & $\mathbf{0 . 4}$ & 8.4 \\
$\mathrm{BU}$ & $\mathbf{0 . 5}$ & -6.7 & $\mathbf{0 . 3}$ & 5.8 & $\mathbf{0 . 6}$ & 3.8 & 0.2 & 5.4 & $\mathbf{0 . 4}$ & 7.4 \\
$\mathrm{SO}$ & $\mathbf{0 . 6}$ & 6.2 & $\mathbf{0 . 3}$ & $\mathbf{1 1 . 4}$ & $\mathbf{0 . 5}$ & 6.7 & 0.2 & 12.0 & $\mathbf{0 . 4}$ & $\mathbf{3 8 . 1}$ \\
$\mathrm{SA}$ & 0.4 & -5.8 & 0.2 & 4.2 & $\mathbf{0 . 5}$ & -2.9 & 0.1 & 4.2 & $\mathbf{0 . 3}$ & 1.7 \\
$\mathrm{BJ}$ & 0.0 & 28.1 & 0.2 & $\mathbf{2 4 . 2}$ & $\mathbf{0 . 4}$ & 2.5 & 0.0 & 27.2 & $\mathbf{0 . 2}$ & $\mathbf{8 4 . 3}$ \\
\hline
\end{tabular}

Statistical significance: $\mathbf{p}<\mathbf{0 . 0 1}$ and $p<0.05$ 


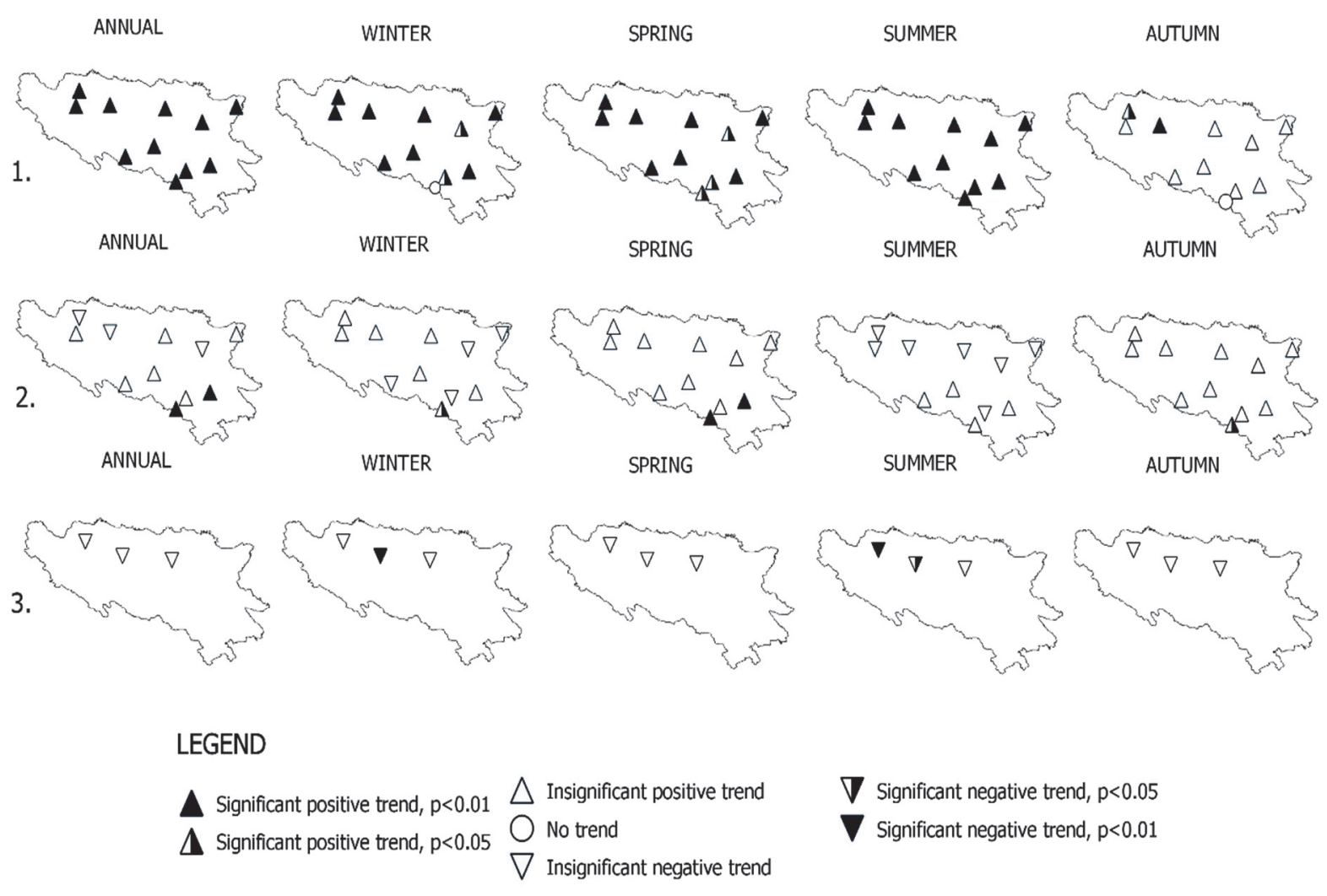

Fig. 2. Annual and seasonal trends in air temperature (1), precipitation (2), and river discharges (3).

\subsection{Changes in river discharges}

Decadal linear trends in mean seasonal and annual river discharges measured at 3 hydrological stations in the SRW in B\&H in the period 1961-2016 are presented in Table 3. Mean annual river discharges displayed statistically insignificant downward tendency at all analyzed hydrological stations. The observed negative trends were also found throughout the year at all stations. Most prominent decrease in river discharges were determined in summer at the Prijedor and Vrbanja stations $\left(-3.9 \mathrm{~m}^{3} / \mathrm{s} / 10\right.$ years and $-2.2 \mathrm{~m}^{3} / \mathrm{s} / 10$ years, respectively), whereas only significant $(\mathrm{p}<0.01)$ negative trend in winter was found at the Vrbanja station. Observed negative trends reflect the warming tendency which has been found particularly in summer and winter, along with weak positive/negative precipitation trends. However, despite the pronounced warming and weak precipitation trends, statistically insignificant discharges trends indicate that precipitation has the greatest impact on river flow. No statistically significant 
negative trend was recorded at the Doboj hydrological station. This probably stems from the fact that the Bosna River basin has the largest watershed with greater capacity to address adverse influence of climate warming compared to the other two sub-basins. The weakest downward tendency was displayed in autumn (i.e., at the Prijedor and Vrbanja stations the trend was almost non-existent) which is in concordance with the low values of air temperature and precipitation trends.

Table 3. Decadal linear trends in average seasonal and annual river discharges $\left(\mathrm{m}^{3} / \mathrm{s}\right)$ measured at 3 hydrological stations over the Sava River watershed in Bosnia and Herzegovina in the period 1961-2016

\begin{tabular}{|c|c|c|c|c|c|c|c|c|c|c|}
\hline \multirow[b]{2}{*}{$\begin{array}{c}\text { River } \\
\text { Station }\end{array}$} & \multicolumn{2}{|c|}{ Winter } & \multicolumn{2}{|c|}{ Spring } & \multicolumn{2}{|c|}{ Summer } & \multicolumn{2}{|c|}{ Autumn } & \multicolumn{2}{|c|}{ Year } \\
\hline & $\underset{\mathbf{m}^{3 / \mathbf{s}}}{\mathbf{Q}}$ & $\begin{array}{c}\begin{array}{c}\text { Trend } \\
\mathrm{m}^{3} / \mathrm{s}- \\
1 / 10 y e a r s\end{array} \\
\end{array}$ & $\underset{\mathrm{m}^{3} / \mathrm{s}}{Q}$ & $\begin{array}{c}\text { Trend } \\
\mathrm{m}^{3} / \mathrm{s}- \\
\text { 1/10years }\end{array}$ & $\begin{array}{c}Q \\
m^{3} / s\end{array}$ & $\begin{array}{c}\text { Trend } \\
\mathrm{m}^{3} / \mathrm{s}- \\
1 / 10 y e a r s\end{array}$ & $\begin{array}{c}Q \\
\mathrm{~m}^{3} / \mathrm{s}\end{array}$ & $\begin{array}{c}\text { Trend } \\
\mathrm{m}^{3} / \mathrm{s}- \\
1 / 10 \text { years }\end{array}$ & $\begin{array}{c}Q \\
\mathrm{~m}^{3} / \mathrm{s}\end{array}$ & $\begin{array}{c}\text { Trend } \\
\mathrm{m}^{3} / \mathrm{s}- \\
1 / 10 \text { years }\end{array}$ \\
\hline $\begin{array}{c}\text { Sana } \\
\text { (Prijedor) }\end{array}$ & 98.2 & -2.1 & 119.7 & -0.5 & 42.0 & -3.9 & 59.2 & -0.6 & 79.6 & -2.6 \\
\hline $\begin{array}{l}\text { Vrbanja } \\
\text { (Vrbanja) }\end{array}$ & 19.5 & -2.2 & 23.9 & -0.2 & 10.5 & -1.2 & 9.4 & -0.5 & 15.8 & -0.6 \\
\hline $\begin{array}{l}\text { Bosna } \\
\text { (Doboj) }\end{array}$ & 198.9 & -11.6 & 246.0 & -4.0 & 105.5 & -5.5 & 106.4 & -2.6 & 163.9 & -6.5 \\
\hline
\end{tabular}

Statistical significance: $\mathbf{p}<\mathbf{0 . 0 1}$ and $\overline{p<0.05}$

\subsection{Correlation among climatic variables and river discharges}

The correlation test results are given in Table 4 and Fig. 3. Considering the strong connection between river discharges and climatic variables we can infer that climate is a key factor which affects river discharges in the SRW. Climatic variables displayed a good correlation with river discharges at annual scale. River discharges were significantly and positively $(p<0.01)$ correlated with precipitation, whereas negative and mainly significant correlation was established between temperature and river discharges. Strong positive correlation between precipitation and river discharges (along with negative correlation between air temperatures and river discharges) throughout the year suggests that precipitation is the primary factor controlling river discharge regimes in the SRW. Moreover, significant $(p<0.01)$ link amongst precipitation and river discharges was found throughout the year, especially in summer and then in winter and autumn. Higher correlation values in the summer are results of maximum, late spring/early summer rainfall events, whereas values of winter correlation coefficients suggest that the share of precipitation that falls as rain increases due to the significant warming tendency in this season. Otherwise, solid precipitation would be stored as a snow and melted later in the spring. Statistically significant connection between air temperature, and river discharge was also detected throughout the 
year, except in the smaller Vrbanja River basin, where discharges greatly depend on precipitation. As expected, the strongest linkage among air temperature and river discharge were determined for summer, when high temperatures amplify the evapotranspiration process. Observed warming trends in the summer across the SRW, along with decrease in precipitation are manifested in negative tendency at each selected hydrological stations. Significant correlation was also found in spring reflecting the upward warming tendency in this season.

Table 4. Correlation among seasonal and annual climatic variables and river discharges over the Sava River watershed in Bosnia and Herzegovina in the period 1961-2016

\begin{tabular}{llcccc}
\hline \hline Vrbanja station & Winter & Spring & Summer & Autumn & Year \\
Precipitation & $\mathbf{0 . 5 6 6}$ & $\mathbf{0 . 6 4 2}$ & $\mathbf{0 . 7 0 4}$ & $\mathbf{0 . 6 9 1}$ & $\mathbf{0 . 7 2 5}$ \\
Temperature & $\mathbf{- 0 . 4 2 6}$ & -0.323 & $\mathbf{- 0 . 4 3 9}$ & -0.245 & -0.393 \\
\hline Prijedor station & Winter & Spring & Summer & Autumn & Year \\
Precipitation & $\mathbf{0 . 7 6 3}$ & $\mathbf{0 . 6 2 4}$ & $\mathbf{0 . 7 1 6}$ & $\mathbf{0 . 6 8 0}$ & $\mathbf{0 . 7 6 8}$ \\
Temperature & -0.158 & $\mathbf{- 0 . 4 1 8}$ & $\mathbf{- 0 . 5 1 1}$ & -0.174 & $\mathbf{- 0 . 3 9 1}$ \\
\hline Doboj station & Winter & Spring & Summer & Autumn & Year \\
Precipitation & $\mathbf{0 . 7 1 9}$ & $\mathbf{0 . 6 1 4}$ & $\mathbf{0 . 7 7 6}$ & $\mathbf{0 . 6 2 8}$ & $\mathbf{0 . 6 7 1}$ \\
Temperature & -0.171 & $\mathbf{- 0 . 4 6 2}$ & $\mathbf{- 0 . 4 5 7}$ & $\mathbf{- 0 . 3 0 4}$ & -0.493 \\
\hline
\end{tabular}

Statistical significance: $\mathbf{p}<\mathbf{0 . 0 1}$ and $p<0.05$

Fig. 3. Correlation among river discharges and air temperature (1) / precipitation (2)

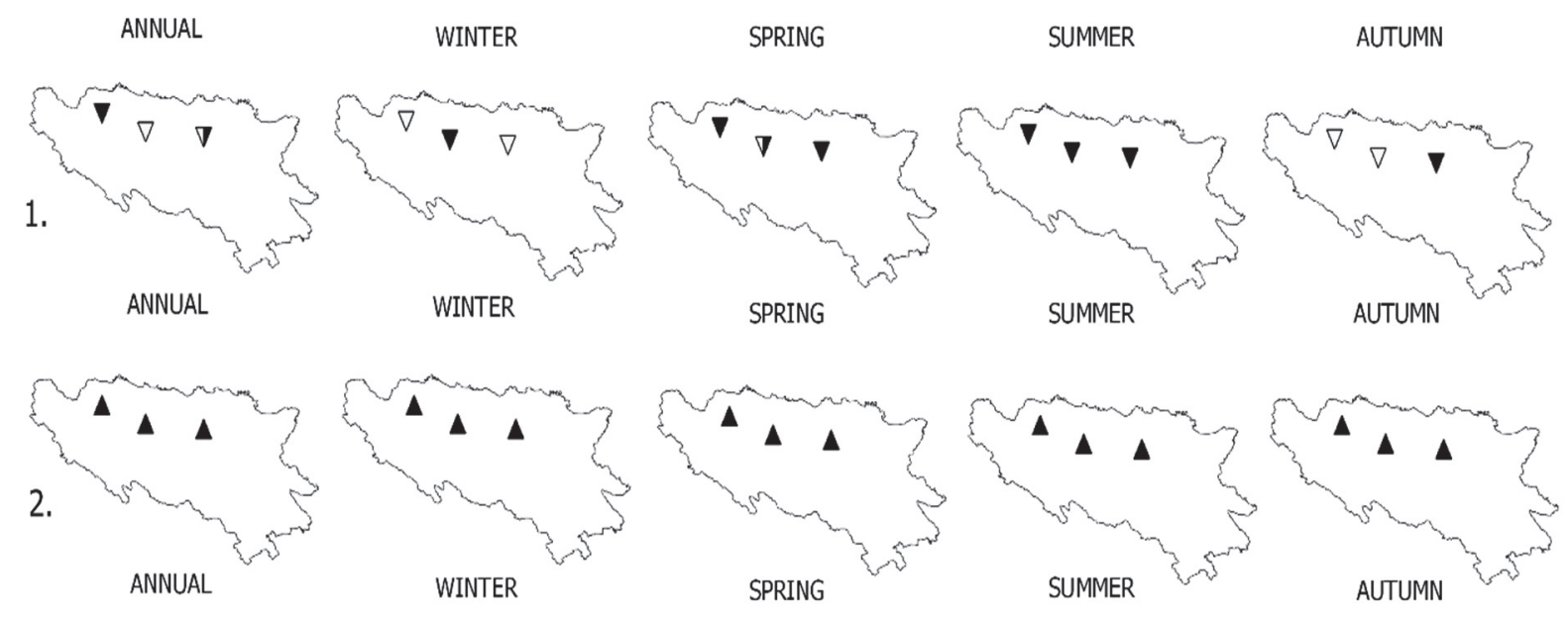

LEGEND

Significant positive correlation, $p<0.01$ 


\section{Conclusion}

The paper investigates changes in mean hydroclimatic variables over the SRW in $\mathrm{B} \& \mathrm{H}$. We provided evidence of a prominent warming tendency along with negative river discharge trends across the study area. Alterations in annual and seasonal climatic and hydrological variables over the SRW during the period 1961-2016 were analyzed based on data sets of average temperatures and precipitation from 11 meteorological stations and 3 hydrological stations. It was proved that climate is significant factor affecting the river discharge regime over the study area. Referring to the correlation analysis it was affirmed, that changes in river discharges are strongly influenced by changes in climatic variables over the entire region. The obtained results suggest that during the 1961-2016 period the whole SRW in B\&H displayed prominent warming tendency on annual scale. Increasing trends in temperature were also found throughout the year, whereas precipitation displayed mainly insignificant trends mixed in sign. As expected, river discharges reflected changes in climatic variables. In a line with observed climatic trends, river discharges showed predominantly negative trends that were mainly insignificant. Given that the most prominent upward tendency was determined for summer and winter along with mainly decreasing precipitation, river discharges displayed the most notable downward tendency in these seasons. Significant positive correlation between precipitation and river discharges points out a very close connection, where changes in precipitation variability have a primary impact on the pattern of changes in river flow. Strongest link between air temperatures and river discharges found for summer indicates that significant climate warming in this part of the year has strong impact over the basin during this season. Increasing temperature and precipitation variability would probably magnify freshwater demand leading to water deficiency (especially in small watersheds) and to various negative natural and economic implications in the SRW. Efficient water management strategy is the key for sustainable water consumption. On this point, this study represents one of the first steps in an attempt to provide detailed hydroclimatic analysis of the SRW as a base for future research. Moreover, big obstacle for more efficient water management is the generally small number of hydrological stations, as well as the absence of longterm measurements. One of the major efforts regarding climate and hydrological monitoring in the future should be orientated towards increasing hydroclimatic station density over the SRW, which will allow us to adopt a more improved adaptation strategy.

Acknowledgements: The paper is the result of the research funded by the Ministry of Scientific and Technological Development, Higher Education and Information Society of the Republic of Srpska. 


\section{References}

Adler, R.F., Gu, G., Sapiano, M., Wang, J-J. and Huffman, G.J., 2017: Global Precipitation: Means, Variations and Trends During the Satellite Era (1979-2014). Surv. Geophys. 38, 679-699. https://doi.org/10.1007/s10712-017-9416-4

Bajat, B., Blagojević, D., Kilibarda, M., Luković, J. and Tošić, I., 2015: Spatial analysis of the temperature trends in Serbia during the period 1961-2010. Theor. Appl. Climatol. 121, 289-301. https://doi.org/10.1007/s00704-014-1243-7

Biao, E. I., 2017: Assessing the impacts of climate change on river discharge dynamics in Oueme River Basin (Benin, West Africa). Hydrology. 4, 47. https://doi.org/10.3390/hydrology4040047

Billi, P. and Fazzini, M., 2017: Global change and river flow in Italy. Glob. Planet. Change 155, 234246. https://doi.org/10.1016/j.gloplacha.2017.07.008

Birsan, M. V., Zaharia, L., Chendes, V. and Branescu, E., 2014: Seasonal trends in Romanian streamflow. Hydrol. Process. 28, 4496-4505. https://doi.org/10.1002/hyp.9961

Burić, D., Ducić, V. and Doderović, M., 2016: Poplave u Crnoj Gori krajem 2010. godine sa osvrtom na kolebanje proticaja Morače. Glasnik Odjeljenja prirodnih nauka, CANU, 21, 47-64. (in Montenegrin)

Burić, D., Luković, J., Ducić, V., Dragojlović, J. and Doderović, M., 2014: Recent trends in daily temperature extremes over southern Montenegro (1951-2010). Nat. Hazards Earth Syst. Sci. 14, 67-72. https://doi.org/10.5194/nhess-14-67-2014

Burić, D., Stanojević, G., Luković, J., Gavrilović, Lj. and Živković, N., 2012: Climate change and river discharge: case study Kolubara River, Beli brod hydrological gauge. Bull. Serbian Geogr. Soc. 92, 123-134. https://doi.org/10.2298/GSGD1201123B

Čanjevac I, and Orešić, D., 2015: Contemporary changes of mean annual and seasonal river discharges in Croatia. Hrvat. Geog. Glas. 77, 7-27. https://doi.org/10.21861/HGG.2015.77.01.01

Cuo, L., Zhang, Y, Zhu, F. and Liang, L. 2014: Characteristics and changes of streamflow on the Tibetan Plateau: A review. J. Hydrol. 2, 49-68. https://doi.org/10.1016/j.ejrh.2014.08.004

Déry, S. J., Stadnyk, T. A., MacDonald, M. K. and Gauli-Sharma, B., 2016: Recent trends and variability in river discharge across northern Canada. Hydrol. Earth Syst. Sci. 20, 4801-4818. https://doi.org/10.5194/hess-20-4801-2016

Dimkić, D., 2018: Observed Climate and Hydrologic Changes in Serbia-What Has Changed in the Last Ten Years. Proceedings 2(11), 616. https://doi.org/10.3390/proceedings2110616

Fei, J., Zhaohua, W., Jianping, H. and Chassignet, E.P., 2014: Evolution of Land Surface Air Temperature Trend. Nat. Clim. Change. 4, 462-466. https://doi.org/10.1038/nclimate2223

Gajić-Čapka, M., Cindrić, K. and Pasarić, Z., 2015: Trends in precipitation indices in Croatia, 19612010. Theor. Appl. Climatol. 121, 167-177. https://doi.org/10.1007/s00704-014-1217-9

Gebremicael, T. G., Mohamed, Y. A., Zaag, P. v. and Hagos, E, Y., 2017: Temporal and spatial changes of rainfall and streamflow in the Upper Tekeze-Atbara river basin, Ethiopia. Hydrol. Earth Syst. Sci. 21, 2127-2142. https://doi.org/10.5194/hess-21-2127-2017

Gu, G. and Adler, R.F., 2015: Spatial Patterns of Global Precipitation Change and Variability during 1901-2010. J. Climate, 28, 4431-4453. https://doi.org/10.1175/JCLI-D-14-00201.1

Hadžić, E. and Drešković, N., 2014: Analysis of the impact of temperature and precipitation fluctuations on river flow in the Sarajevo valley. Vodoprivreda, 46, 65-75.

Hannaford, J. and Buys, G., 2012: Trends in seasonal river flow regimes in the UK. J. Hydrol. 475, 158-174. https://doi.org/10.1016/j.jhydrol.2012.09.044

Ilešič, S., 1948: Rečni režimi v Jugolsaviji. Geogr. Vestn. 19, 71-110. (in Slovenian)

IPCC, 2014: Climate change 2014: impacts, adaptation, and vulnerability. Part A: Global and sectoral aspects. Contribution of Working Group II to the Fifth Assessment Report of the Intergovernmental Panel on Climate Change [Field, C. B., Barros, V. R., Dokken, D. J., Mach, K. J., Mastrandrea, M. D., Bilir, T. E., Chatterjee, M., Ebi, K. L., Estrada, Y. O., Genova, R. C., Girma, B., Kissel, E. S., Levy, A. N., MacCracken, S., Mastrandrea, P. R., White, L. L. (eds.)]. Cambridge University Press, Cambridge, United Kingdom and New York, NY, USA. 
Jiménez Cisneros, B. E., Oki, T., Arnell, N. W., Benito, G., Cogley, J. G., Döll, P., Jiang, T., Mwakalila, S. S., 2014: Freshwater resources. In (Eds.: Field, C. B., Barros, V. R., Dokken, D. J., Mach, K. J., Mastrandrea, M. D., Bilir, T. E., Chatterjee, M., Ebi, K. L., Estrada, Y. O., Genova, R. C., Girma, B., Kissel, E. S., Levy, A. N., MacCracken, S., Mastrandrea, P. R. and White, L. L.) Climate change 2014: impacts, adaptation, and vulnerability. Part A: global and sectoral aspects. Contribution of Working Group II to the Fifth Assessment Report of the Intergovernmental Panel on Climate Change. Cambridge University Press, Cambridge, 229-269.

Kong, Y. and Pang, Z., 2013: Statistical analysis of stream discharge in response to climate change for Urumqi River catchment, Tianshan Mountains, central Asia. Quat. Int. 336, 44-51.. https://doi.org/10.1016/j.quaint.2013.05.002

Kormann, C., Francke, T., Renner, M. and Bronstert, A., 2015: Attribution of high resolution streamflow trends in Western Austria - an approach based on climate and discharge station data. Hydrol. Earth Syst. Sci. 19, 1225-1245. https://doi.org/10.5194/hess-19-1225-2015

Kovačević-Majkić, J. and Urošev, M., 2014: Trends of mean annual and seasonal discharges of rivers in Serbia. J. Geogr. Inst. Cvijic. 64, 143-160. https://doi.org/10.2298/IJGI1402143K

Lorenzo-Lacruz, J., Vicente-Serrano, S.M., López-Moreno, J.I., Morán-Tejeda, E. and Zabalza, J., 2012: Recent trends in Iberian streamflows (1945-2005). J. Hydrol. 414-415, 463-475. https://doi.org/10.1016/j.jhydrol.2011.11.023

Luković, J., Bajat, B., Blagojević, D. and Kilibarda, M., 2014: Spatial pattern of recent rainfall trends in Serbia (1961-2009). Reg. Environ. Change 14, 1789-1799. https://doi.org/10.1007/s10113-013-0459-x

Lutz, S.R., Mallucci, S., Diamantini, E., Majone, B., Bellin, A. and Merz, R., 2016: Hydroclimatic and water quality trends across three Mediterranean river basins. Sci. Total Environ. 571, 1392-1406. https://doi.org/10.1016/j.scitotenv.2016.07.102

Madakumbura, M.D., Kim, H., Utsumi, N., Shiogama, H., Fischer, E. M., Seland, Ø., Scinocca, J, F., Mitchell, D. M., Hirabayashi, Y. and Oki, T., 2019: Event-to-event intensification of the hydrologic cycle from $1.5^{\circ} \mathrm{C}$ to a $2{ }^{\circ} \mathrm{C}$ warmer world. Sci. Rep. 9, 3483. https://doi.org/10.1038/s41598-019-39936-2

Mamara, A., Argiriou, A.A. and Anadranistakis, M., 2016: Recent trend analysis of mean air temperature in Greece based on homogenized data. Theor. Appl. Climatol. 126, 543-573. https://doi.org/10.1007/s00704-015-1592-x

Masseroni, D., Camici, S., Cislaghi, A., Vacchiano, G., Massari, C. and Brocca, L., 2020: 65-year changes of annual streamflow volumes across Europe with a focus on the Mediterranean basin. Hydrol. Earth Syst. Sci. Discuss. Preprint. https://doi.org/10.5194/hess-2020-21

Orešić, D., Čanjevac, I. and Plantak, M., 2018: Changes in flow and the discharge regime on the Ilova river. Acta Geogr. Cro. 43-44, 1-20.

Pasquini, A. I. and Depetris, P. J., 2007: Discharge trends and flow dynamics of South American rivers draining the Southern Atlantic seaboard: An Overview. J. Hydrol. 33, 385-399. https://doi.org/10.1016/j.jhydrol.2006.09.005

Popov, Gnjato, S., Trbić, G. and Ivanišević, M., 2018a: Recent trends in extreme temperature indices in Bosnia and Herzegovina. Carpath. J. Earth. Env. 13, 211-224.

https://doi.org/10.26471/cjees/2018/013/019

Popov, Gnjato, S., Trbić, G. and Ivanišević, M., 2018b: Analysis of extreme precipitation indices in the East Herzegovina (Bosnia and Herzegovina). J. Geogr. Inst. Cvijic. 69, 1-16. https://doi.org/10.2298/IJGI1901001P

Popov, T., Gnjato, S. and Trbić, G., 2018c: Analysis of extreme precipitation over the Peripannonian region of Bosnia and Hercegovina. Időjárás 122, 433-452. https://doi.org/10.28974/idojaras.2018.4.5

Radevski, I., Gorin, S., Taleska, M. and Dimitrovska, O., 2018: Natural regime of streamflow trends in Macedonia. Geografie 123. 1-20. https://doi.org/10.37040/geografie2018123010001

Radusin, S., Medić, V., Cero, M., Abdurahmanović, I., Avdić, S., Oprašić, S., Avdić, S., Bajrović, A.S., Muharemović, A., Prašović, S., Trbić, G., Husika, A., Krajinović, B., Stojanović, B., Zorić, B., Bajić, D., Vojinović, Đ., Arnautović-Aksić, D., Zahirović, E., Krečinić, E., Omerčić, E., Kupusović, E., Tica, G., Čustović, H., Musić, I., Čizmić, I., Koprena, J., Čolović-Daul, M., Tais, M., Voloder, M., Ljuša, M., Karabegović, M., Mataruga, M., Kotur, M., Rudan, N., Drešković, 
N., Begović, P., Dekić, R., Gnjato, R., Radić, R., Hodžić, S., Kopranović, S., Stupar, S., Blagojević, V., Đurđević, V., Vujković Z., Hydrometeorological Service \& Federal Hydrometeorological Service. 2016: Third national communication and second biennial update report on greenhouse gas emissions of Bosnia and Herzegovina under the United Nations framework convention on climate change. UNDP, Sarajevo

Rottler, E., France, T., Bürger, G. and Bronstert, A., 2020: Long-term changes in central European river discharge for 1869-2016: impact of changing snow covers, reservoir constructions and an intensified hydrological cycle. Hydrol. Earth Syst. Sci. 24, 1721-1740.

https://doi.org/10.5194/hess-24-1721-2020

Saraiva Okello, A. M. L., Masih, I., Uhlenbrook, S, Jewitt, G. P. W., van der Zaag, P. and Riddell, E., 2015: Drivers of spatial and temporal variability of streamflow in the Incomati River basin. Hydrol. Earth Syst. Sci. 19, 657-673. https://doi.org/10.5194/hess-19-657-2015

Schneider, C., Laize, C. L. R., Acreman, M, C. and Florke, M., 2013: How will climate change modify river flow regimes in Europe? Hydrol. Earth Syst. Sci. 17, 325-339.

https://doi.org/10.5194/hess-17-325-2013

Sidibe, M., Dieppois, B., Mahé, G., Paturel, J.-E., Amoussou, E., Anifowose, B., and Lawler, D., 2018: Trend and variability in a new, reconstructed streamflow dataset for West and Central Africa, and climatic interactions, 1950-2005. J. Hydrol. 561, 478-493.

https://doi.org/10.1016/j.jhydrol.2018.04.024

Souvignet, M., Laux, P., Freer, J., Cloke, H., Thinh, D. Q., Thuc, T., Cullmann, J., Nauditt, A., Flügel, W. A., Kunstmann, H. and Ribbe, L., 2014: Recent climatic trends and linkages to river discharge in Central Vietnam. Hydrol. Process. 28, 1587-1601.

https://doi.org/10.1002/hyp.9693

Stahl, K., Hisdal, H., Hannaford, J., Tallaksen, L., Van Lanen, H., Sauquet, E., Demuth, S., Fendekova, M. and Jordar, J., 2010: Streamflow trends in Europe: evidence from a dataset of near-natural catchments. Hydrol. Earth Syst. Sci. 14, 2367-2382. https://doi.org/10.5194/hess-14-2367-2010

Su, L., Miao, C., Kong, D., Duan, Q., Lei, X., Hou, $Q$., and $L i, H$., 2018: Long-term trends in global river flow and the causal relationships between river flow and ocean signals. J. Hydrol. 563, 818-833. https://doi.org/10.1016/j.jhydrol.2018.06.058

Tamaddun, K., Kalra, A. and Ahmad, S., 2016: Identification of Streamflow Changes across the Continental United States Using Variable Record Lengths. Hydrology 3, 24. https://doi.org/10.3390/hydrology3020024

Tananaev, N. I., Makarieva, O.M. and Lebedeva, L. S., 2016: Trends in annual and extreme flows in the Lena River basin, Northern Eurasia. Geophys. Res. Lett. 43, 10764-10772. https://doi.org/10.1002/2016GL070796

Trbić, G., Popov, T. and Gnjato, S., 2017: Analysis of air temperature trends in Bosnia and Herzegovina. Geogr. Pannonica 21, 68-84. https://doi.org/10.5937/GeoPan1702068T

van der Schrier, D., van den Besselaar, E.J.M., Klein Tank, A.M.G. and Verver, G., 2013: Monitoring European average temperature based on the E-OBS gridded data set. J. Geophys. Res. Atmos. 118, 5120-5135. https://doi.org/10.1002/jgrd.50444

van Vliet, M, T, H., Franssen, W. H. P., Yearsley, J. R., Ludwig, F., Haddeland, I., Lettenmaier, D, P. and Kabat, P., 2013: Global river discharge and water temperature under climate change. Glob. Environ. Change 23, 450-464. https://doi.org/10.1016/j.gloenvcha.2012.11.002

Wang, W., Wei, J., Shao, Q., Xing, W., Yong, B., Yu, Z. and Jiao, X., 2015: Spatial and temporal variations in hydro-climatic variables and runoff in response to climate change in the Luanhe River basin, China. Stoch. Environ. Res. Risk. A. 29, 1117-1133. https://doi.org/10.1007/s00477-014-1003-3

Wilson, D., Hisdal, H. and Lawrence, D., 2010: Has streamflow changed in the Nordic countries? Recent trends and comparisons to hydrological projections. J. Hydrol. 394, 334-346. https://doi.org/10.1016/j.jhydrol.2010.09.010

Yeste, P., Dorador, J., Martin-Rosales, W., Molero, E., Esteban-Parra, M. J. and Rueda, F. J., 2018: Climate-driven trends in the streamflow records of a reference hydrologic network in Southern Spain. J. Hydrl. 566, 55-72. https://doi.org/10.1016/j.jhydrol.2018.08.063

Zhang, X.S., Amirthanathen, G.E., Bari, M. A., Laugesen, R. M., Shin, D., Kent, D.M., MacDonlad, A. M., Turner, M. E. and Tuteja, N. K., 2016: How streamflow has changed across Australia since the 1950s: evidence from the network of hydrologic reference stations. Hydrol. Earth Syst. Sci. 20, 3947-3965. https://doi.org/10.5194/hess-20-3947-2016 